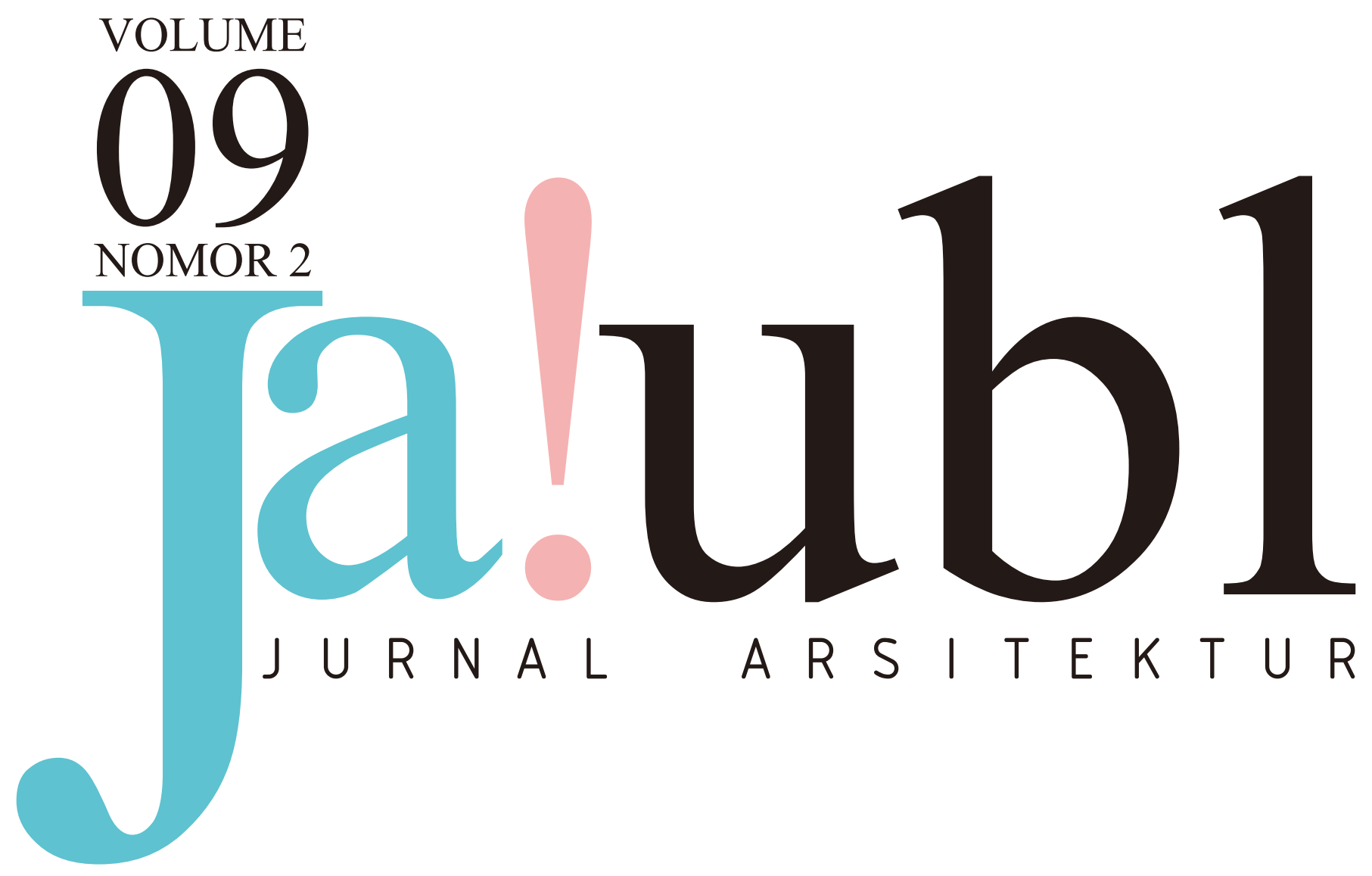


JA!UBL - Jurnal Arsitektur

Terbit dua kali setahun pada bulan Januari dan Juli. Diterbitkan oleh Program Studi Arsitektur Fakultas Teknik Universitas Bandar Lampung. JA!UBL merupakan media pendokumentasian, sharing, dan publikasi karya ilmiah yang berisi karya-karya riset ilmiah mengenai bidang ilmu perancangan arsitektur dan bidang ilmu lain yang sangat erat kaitannya seperti perencanaan kota dan daerah, desain interior, perancangan lansekap, dan sebagainya.

ISSN: 2087-2739

\section{PELINDUNG}

Dr. Ir.H.M.Yusuf Barusman, M.B.A. (Universitas Bandar Lampung)

\section{PENASEHAT}

Dr. Ir. Hery Riyanto, M.T. (Universitas Bandar Lampung)

PENANGGUNG JAWAB

Ir. Tjetjeng Sofjan S., M.M., M.T. (Universitas Bandar Lampung)

\section{PIMPINAN REDAKSI}

Dr.Eng. Haris Murwadi, S.T., M.T.

\section{REDAKSI PELAKSANA}

Shofia Islamia Ishar, S.T., M.T.

Dadang Hartabela, S.T., M.T.

Ai Siti Munawaroh, S.Pd., M.I.L.

Indyah Kumoro Wardani, S.T., IAI

\section{DEWAN REDAKSI}

Prof. Dr. Julaihi Wahid (Universitas Sains Malaysia)

Prof. Dr. Ir. H. Slamet Tri Sutomo, M.S (Universitas Hasanuddin)

Prof. Ir. Totok Rusmanto, M.Eng. (Universitas Diponegoro)

Prof. Dr. Ing. Ir Gagoek Hardiman. (Universitas Diponegoro)

Dr.Eng. Fritz Akhmad Nuzir, S.T., M.A.(L.A.) (Universitas Bandar Lampung)

David Hutama, ST., M.Eng (Universitas Pelita Harapan)

\section{MITRA BESTARI}

Dr. Ir. Budi Prayitno, M.Eng. (Universitas Gajah Mada)

Dr. Eng. Ir. Ahmad Sarwadi, M.Eng (Universitas Gajah Mada)

Prof. Dr. T. Yoyok Wahyu Subroto, M.Eng. Ph. D. (Universitas Gajah Mada)

Dr.Eng. Fritz Akhmad Nuzir, S.T., M.A. (L.A.) (Universitas Bandar Lampung)

Prof. Ir. Liliany Sigit Arifin, M.Sc., Ph. D (Universitas Petra)

Dr. Budi Faisal (Institut Teknologi Bandung)

Dr.Eng. Agus Hariyadi, S.T., M.Sc. (Universitas Gajah Mada)

\section{TIM GRAFIS DESAIN}

Satrio Agung Perwira

B. Chrysvania Artemisia

\section{ALAMAT REDAKSI}

Program Studi Arsitektur Fakultas Teknik Universitas Bandar Lampung

Jalan Zainal Abidin Pagar Alam Nomor. 26 Labuhanratu, Bandarlampung, 35142

Telp. $\quad:$ :0721-773847

E-mail : : editor.j@ubl.ac.id

Homepage : ubl.ac.id 


\section{Daftar Isi Artikel}

01-06 Analisis Penerapan Art Deco pada Rumah di Bandung Periode Perang Dunia I-II Studi Kasus: Tiga Villa dan Perumahan Dosen UPI FADILASARI, Dewi

07-12 Tipologi Bentuk Atap pada Arsitektur Jawa ROOSANDRIANTINI, Josephine; SANTOSO, Angelina Novemita; AMBARWATI, Catherina Novita

13-18 Identifikasi Respon Pengunjung mengenai Keberadaan Desa Wisata Taman Purbakala Pugungraharjo Lampung HARTABELA, Dadang; MASITO, Yuni

19-26 Fenomena Terbentuknya Ruang Spatio-Temporal di Kawasan Stadion Pahoman Bandarlampung WIBAWA, M. Shubhi Yuda

27-32 Identifikasi Area Berpotensi Macet di Kawasan Pendidikan Jl. Z.A. Pagar Alam Bandarlampung PERWIRA, Satrio Agung; MURWADI, Haris; MUNAWAROH, Ai Siti; ISHAR, Shofia Islamia

33-40 Manfaat Ruang Terbuka dan Hubungannya dengan Kegiatan Interaksi Sosial Studi Kasus: Perumahan Nusa Tamalanrea Indah Makassar NURHIJRAH; WIKANTARIA, Ria 


\title{
Analisis Penerapan Art Deco Pada Rumah di Bandung Periode Perang Dunia I-II Studi Kasus: Tiga Villa dan Perumahan Dosen UPI
}

\author{
Dewi Fadilasari ${ }^{1 *}$ \\ ${ }^{1}$ Program Studi Teknik Sipil, Fakultas Teknik, Universitas Malahayati \\ *Penulis Korespondensi: d.fadilasari@malahayati.ac.id; Telp. +62 8119780155
}

\begin{abstract}
Abstrak:
Gaya Art Deco merupakan gaya yang berkembang pertama kali di Perancis, pada periode Perang Dunia I hingga Perang Dunia II, yang dikenal juga dengan periode interwar. Perkembangan gaya Art Deco pada bangunan di Indonesia dibawa oleh para arsitek Belanda yang bekerja sekaligus menetap di Indonesia dan salah satu kota di Indonesia yang paling kaya akan bangunan bergaya Art Deco adalah kota Bandung. Tujuan dilakukannya penelitian ini adalah untuk menganalisis bagaimana gaya Art Deco diterapkan pada bangunan yang memiliki fungsi awal sebagai rumah tinggal di Bandung, periode Perang Dunia I hingga Perang Dunia II, berikut faktorfaktor yang mempengaruhi penerapannya, sehingga didapatkan gambaran yang pasti mengenai Art Deco pada bangunan-bangunan rumah tinggal tersebut, yang dalam penelitian ini mengambil studi kasus bangunan Tiga Villa dan Perumahan Dosen UPI. Adapun metode penelitian yang digunakan adalah metode penelitian kualitatif untuk mendapatkan kejelasan mengenai penerapan Art Deco pada bangunan-bangunan rumah tinggal di Bandung, periode Perang Dunia I hingga Perang Dunia II. Dimana hal tersebut mencakup sejarah masuknya Art Deco ke Bandung, dan pengkajian teori-teori mengenai Art Deco, berikut perubahan-perubahan yang terjadi, beserta faktor penyebab perubahan tersebut. Hasil dari penelitian ini menunjukan bahwa bangunan Tiga Villa dan Perumahan Dosen UPI ini secara keseluruhan berbentuk utilitarian house, dimana bentuk ini merupakan bentuk bangunan yang masif, yang dipadukan dengan bentuk-bentuk streamline dengan balkon dan lantai atap bangunan yang berbentuk melengkung plastis mengalir (streamline) dan masif. Sedangkan penerapan Art Deco pada bentuk fasad bangunan terlihat dari permainan perbedaan ketinggian fasad, dan kanopi-kanopi yang membentuk elemen garis horisontal, hingga penerapan bentuk-bentuk porthole dan garis-garis fasad yang tegas. Berdasarkan analisis yang telah dilakukan, maka dapat disimpulkan bahwa secara garis besar, penerapan gaya Art Deco pada bangunanbangunan rumah tinggal di Bandung periode Perang Dunia I hingga Perang Dunia II yang berlangsung antara tahun 1914 - 1943, berupa penggunaan bentuk-bentuk streamline plastis maupun masif, atau geometris dan linear, ataupun penggabungan kedua bentuk tersebut pada bentuk badan bangunan. Sementara itu, dekorasi yang banyak dipakai adalah berupa garis-garis lurus vertikal dan horisontal, kurva melengkung, serta bentuk geometris.
\end{abstract}

Kata Kunci: Art Deco; arsitektur; arsitektur modern; perang dunia; bangunan konservasi.

\section{Latar Belakang}

Gaya Art Deco merupakan gaya yang berkembang pertama kali di Perancis, pada periode Perang Dunia I hingga Perang Dunia II, yang dikenal juga dengan periode interwar. Penerapan gaya Art Deco pada masa perkembangannya terdapat pada hampir seluruh bentuk art, mulai dari arsitektur, seni lukis, seni patung, desain grafis, furniture, desain interior, fashion dan lain sebagainya. Sedemikian hebatnya pengaruh gaya Art Deco pada masa itu, sehingga selain mampu masuk ke dalam beragam bentuk seni, juga mampu menyebar hampir keseluruh penjuru dunia, mulai dari Eropa, Amerika, Australia, bahkan Asia. Khusus dalam bidang arsitektur, penerapan gaya Art Deco antara negara yang satu dengan yang lain pada prinsipnya memiliki kesamaan bentuk dan dekorasi. Namun, ada juga beberapa bangunan yang menggunakan muatan lokal budaya setempat sebagai dekorasi pada bangunan, tetapi tetap dikombinasikan dengan sentuhan khas gaya Art Deco.

Perkembangan Art Deco tidak lepas dari pengaruh situasi dan kondisi pada jamannya. Dimana pada saat itu Eropa sedang berkembang revolusi industri, sehingga banyak temuan-temuan mutakhir yang menyebabkan masyarakat terpesona pada penemuan- penemuan dan teknologi yang maju dengan pesat tersebut. Karakterkarakter teknologi yang menggambarkan kecepatan diterjemahkan kedalam desain dengan bentuk garis-garis kurva lengkung mengalir (streamline), garis-garis lurus horizontal maupun vertikal, serta garis-garis zig-zag.

Sementara itu, perkembangan gaya Art Deco pada bangunan di Indonesia dibawa oleh para arsitek Belanda yang bekerja di Indonesia. Hampir semua kota-kota di Indonesia baik besar maupun kecil mempunyai peninggalan bangunan dengan gaya Art Deco. Di Indonesia Art Deco sangat banyak dipengaruhi oleh gaya De 
Stijl dari Belanda yang juga berkembang pada jaman yang bersamaan. Art Deco selain menerima ornamenornamen historis dan mengolahnya dengan gaya dan material yang baru, gaya ini juga menerima pengaruh aliran arsitektur yang sedang berkembang saat itu. Gerakan arsitektur modern yang sedang berkembang pada saat itu ikut mempengaruhi gaya Art Deco serta memberikan sentuhan-sentuhan modern. Modern pada saat itu diartikan dengan "berani tampil beda dan baru, tampil lebih menarik dari yang lain dan tidak kuno" kesemuannya itu dimanifestasikan dengan pemilihan warna yang mencolok, proporsi yang tidak biasa, material yang baru dan dekorasi.

Salah satu kota di Indonesia yang paling kaya akan bangunan bergaya Art Deco adalah kota Bandung. Tempo dulu kota Bandung merupakan sebuah koloni pemukiman orang barat. Dimana banyak pejabat- pejabat Belanda memiliki rumah dan bermukim di Bandung. Mereka tetap mempertahankan suasana lingkungan hidup seperti di Eropa. Mulai dari tradisi gaya hidup sehari-hari, menu dan jenis makanan, cara berpakaian hingga bentuk bangunan rumah tinggal mengikuti gaya yang sedang berkembang di Eropa (Haryoto Kunto, 1984). Karya arsitek Belanda yang paling berpengaruh seperti CPW Schoemaker dan AF Albers juga banyak terdapat di kota Bandung ini.

Dikarenakan banyaknya bangunan bergaya Art Deco yang terdapat di Bandung, terutama bangunan rumah tinggal, maka akan sangat menarik untuk dilakukan penelitian terhadap penerapan gaya Art Deco pada bangunanbangunan yang fungsi asalnya merupakan bangunan rumah tinggal yang diduga bergaya Art Deco, yang ada di Bandung. Walalupun bangunan- bangunan rumah tinggal tersebut kini banyak yang beralih fungsi menjadi bangunan komersial atau kantor. Sehingga penelitian ini hanya dibatasi pada bangunan- bangunan dengan fungsi asal rumah tinggal yang didirikan pada periode Perang Dunia I hingga Perang Dunia II saja. Hal ini dikarenakan pada masa diantara Perang Dunia tersebut merupakan masa perkembangan gaya Art Deco di dunia. Tujuan dilakukannya penelitian ini adalah untuk menganalisis bagaimana gaya Art Deco diterapkan pada bangunan yang memiliki fungsi awal sebagai rumah tinggal di Bandung, periode Perang Dunia I hingga Perang Dunia II, berikut faktor- faktor yang mempengaruhi penerapannya, sehingga didapatkan gambaran yang pasti mengenai Art Deco pada bangunan-bangunan rumah tinggal tersebut.

\section{Metode}

Adapun metode penelitian yang digunakan adalah metode penelitian kualitatif untuk mendapatkan kejelasan mengenai penerapan Art Deco pada bangunan- bangunan rumah tinggal di Bandung, periode Perang Dunia I hingga Perang Dunia II. Dimana hal tersebut mencakup sejarah masuknya Art Deco ke Bandung, dan pengkajian teori-teori mengenai Art Deco, berikut perubahan-perubahan yang terjadi, beserta faktor penyebab perubahan tersebut. Sehingga dapat ditarik sebuah kesimpulan mengenai penerapan Art Deco pada rumah di Bandung, Periode Perang Dunia I hingga Perang Dunia II. Dalam rangka mencari kejelasan inilah maka perlu dilakukan penelitian yang bersifat mencari kejelasan (explanatory research) (Francis C Dane, 1990).

\subsection{Metode Pengumpulan Data}

Metode pengambilan data yang digunakan adalah dengan cara mengumpulkan data-data mengenai bangunanbangunan rumah tinggal di Bandung yang dibangun pada rentang periode Perang Dunia I hingga Perang Dunia II, lalu memilah bangunan mana sajakah yang akan dijadikan sebagai objek penelitian. Setelah itu dilakukan observasi secara langsung dilapangan melalui survei dan pengamatan terhadap objek- objek penelitian tersebut. Kemudian dilakukan pengambilan foto- foto objek penelitian, serta penggalian teori- teori dan literatur mengenai Art Deco. Dalam hal ini, dipilihlah 2 bangunan rumah di Bandung, yang dibangun pada periode Perang Dunia I hingga Perang Dunia II. Adapun bangunan rumah yang dipilih antara lain :

1. Rumah Tiga Villa, Juanda

2. Perumahan dosen UPI

\subsection{Metode Analisis Data}

Data yang telah terkumpul akan dianalisis dengan menggunakan metode kualitatif. Dimana data lapangan yang berupa hasil survei dan observasi secara langsung akan disandingkan dan diinterpretasikan dengan teori-teori yang terdapat di dalam beberapa literatur.

\section{Hasil dan Pembahasan}

\subsection{Art Deco}

Arsitektur Art Deco merupakan sebuah arsitektur ornamen, geometri, energi, optimisme, warna, tekstur dan cahaya, bahkan simbolisme, secara arsitektural dekoratif, yang berkembang diantara dua Perang Dunia. Pada akhir perkembangannya merefleksikan dekade pada masa itu, dimana teknologi sedang berkembang pesat dan nilai estetika merupakan apresiasi dari kekaguman teknologi modern saat itu, mulai dari bentuk mobil, hingga bentuk streamline-nya pesawat terbang atau kemegahan kapal- kapal laut, serta idealisasi terhadap bentuk manusia 
(Alaistair Duncan).

Aristektur Art Deco muncul setelah berakhirnya arsitektur Art Nouveau. Periode yang mengekspresikan masa perpindahan Art Nouveau menuju Art Deco dapat disebut sebagai periode Ornamental Deco (Dibyo Hartono, 2006). Pada periode ini tema tubuh manusia menjadi salah satu pilihan sebagai ornamen bangunan. Selain itu, relief geometris dengan bahan semen, jendela kaca- patri juga berkembang terus dengan tema- tema simbolis yang biasa digunakan pada waktu itu, diantaranya dengan tema sinar matahari yang melambangkan sumber bagi kehidupan manusia.

Dalam perkembangan tujuh tahun kemudian, banyak digunakan pola- pola geometris yang memiliki kesamaan dengan karya arsitek dari kelompok Amsterdam School. Periode ini sering disebut sebagai Geometric Deco atau Zigzag Deco (Dibyo Hartono, 2006). Pada periode akhir dasawarsa ketiga, banyak menghasilkan pola hias garis horizontal. Garis-garis horizontal yang tumbuh dari garis-garis struktur lantai beton dan elemen kanopi beton, yang menciptakan suatu penampilan garis-garis lurus horizontal. Konsep ini dapat dianggap sebagai Horizontal Straight-line Deco (Dibyo Hartono, 2006).

Dalam akhir dasawarsa keempat, bentuk dekorasi garis-garis terlihat semakin plastis dan mengalir (streamline) yang banyak ditemukan pada karya-karya bangunan pada akhir tahun 30-an, yang mengikuti bentuk-bentuk plastis bangunan modern. Dalam dasawarsa tersebut, tumbuhlah suatu pendapat tentang adanya gaya plastis dan erodinamis yang dikenal dengan istilah Streamline Deco.

Gaya Art Deco dianggap spesial dan berbeda. Hal ini dikarenakan Art Deco merupakan gaya pertama yang benar-benar merepresentasikan cerminan abad ke-20 dan berkembang secara internasional. Art Deco merupakan sebuah gaya yang dapat diadaptasi kedalam setiap ciptaan manusia tanpa mengindahkan aplikasi ataupun budget. Selain itu Art Deco merupakan sebuah gaya yang sangat total, seperti Baroque, Klasik ataupun Regency, Art Deco dapat memberikan ornamen pada sebuah rumah, kapal pesiar ataupun sebilah pisau. Tidak ada lagi gaya lain yang mampu mewarnai dan menghiasi hidup kita secara menyeluruh selain gaya Art Deco tersebut.

Semangat Art Deco merupakan semangat dari modernitas. Walaupun Art Deco diadaptasi dari gaya yang lebih tua dari penggunaannya sendiri, namun Art Deco tetap merupakan gaya yang baru. Hal ini disebabkan karena Art Deco merepresentasikan gaya lama, tapi membumbuinya dengan bahan-bahan baru, serta menginterpretasikan ide-ide lama dengan cara baru.

Di Perancis Selatan, rumah-rumah diberi dekorasi floral di dinding, adanya penggunaan kerajinan terbuat dari metal. Adanya jendela porthole, kantilever "eyebrow". Bentuk bangunan sangat geometris, atau linear atau streamline ataupun perpaduan dari ketiganya banyak berkembang pada tahun 30-an. Rumah-rumah model ini disebut utilitarian house. Pada bangunan ini hampir tidak ada dekorasi, kalaupun ada biasanya hanya berupa garis-garis horisontal maupun vertikal, serta tidak adanya permainan warna pada bangunan. Ditemukan juga adanya penggunaan segmen-segmen bertingkat.

\subsection{Art Deco pada Bangunan Rumah Tinggal di Bandung}

Berdasarkan sejarah perkembangan kota dan dari inventarisasi arsitektur bersejarah, kota Bandung diperkirakan memiliki peninggalan Arsitektur Modern yang paling kaya diantara kota-kota besar di Indonesia. Kesimpulan ini ditarik berdasarkan alasan adanya rencana pemerintah Belanda untuk menjadikan kota Bandung sebagai ibukota Hindia Belanda (Bandoeng als hofdstad van Indie) setelah Perang Dunia Pertama. Perubahan wajah Bandung dari sebuah kota kecil menjadi sebuah kota yang tertata rapi dan indah terjadi sejak tahun 1915, mengiringi perpindahan pusat militer dari Batavia ke Bandung dan persiapan untuk menjadikan Bandung sebagai ibu kota pemerintahan Hindia Belanda.

\subsubsection{Tiga Vila Juanda}

Tiga Villa merupakan 3 buah bangunan villa dengan desain yang sama, yang dahulunya berfungsi sebagai rumah peristirahatan atau villa. Arsitek perancang bangunan tersebut adalah A. F. Albers dan dibangun pada tahun 1937. Ketiga bangunan terletak di Jalan Juanda $111-115$.

Bangunan Tiga Villa ini secara keseluruhan berbentuk utilitarian house, dimana bentuk ini merupakan bentuk bangunan yang masif, yang dipadukan dengan bentuk-bentuk streamline. Bentuk utilitarian house merupakan bentuk yang banyak berkembang pada tahun 1930-an. Penggunaan gaya Art Deco sangat kental terasa pada balkon dan lantai atap bangunan yang berbentuk melengkung plastis mengalir (streamline) dan masif. Pada ketiga bangunan tidak terdapat penggunaan dekorasi mencolok. Art Deco lebih banyak diterapkan pada bentuk fasad bangunan yang bermain pada perbedaan ketinggian fasad, dan kanopi-kanopi yang membentuk elemen garis horizontal. Dilihat dari desain bangunan tiga Villa ini secara keseluruhan, maka bangunan ini diklasifikasikan ke dalam streamline deco. 

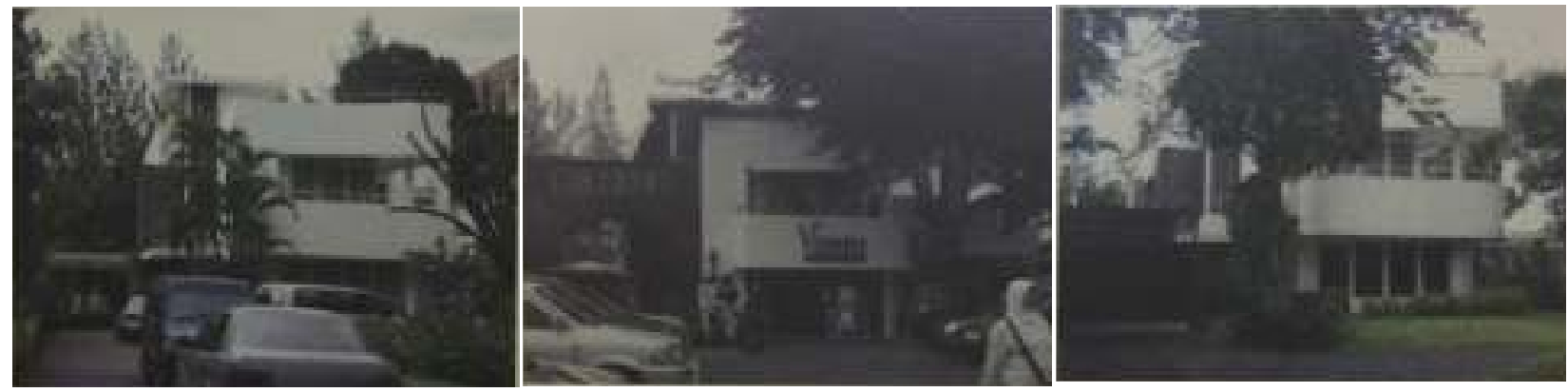

Gambar 1. Bangunan Tiga Villa

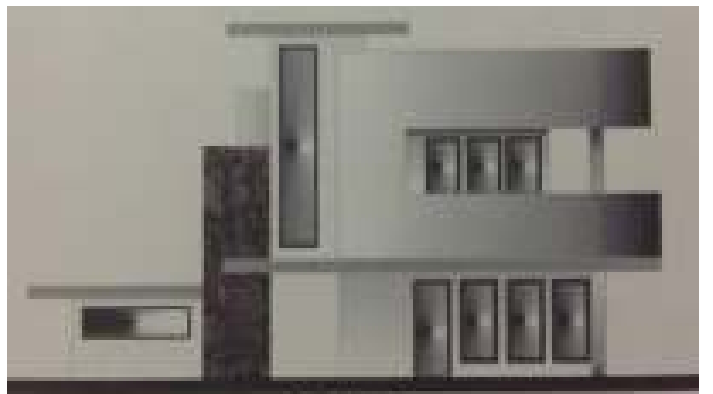

Gambar 2. Fasad Salah Satu Bangunan Tiga Villa

\subsubsection{Perumahan Dosen UPI}

Perumahan dinas para dosen Universitas Pendidikan Indonesia (UPI) ini dahulunya merupakan komplek Perumahan Isola. Terletak di jalan Setiabudhi No. 211, 213, 215, 217, 219, 221, 223, 225. Dibangun pada tahun 1933, dan di desain oleh seorang arsitek Belanda, C. P. W. Schoemaker. Gaya Art Deco banyak diterapkan pada bentuk bangunan. Beberapa bangunan rumah menggunakan bentuk streamline. Yang dikombinasikan dengan bentuk geometris dan linear. Namun adapula bangunan rumah tinggal yang benar-benar berbentuk geometris tanpa melibatkan bentuk streamline di dalamnya, dengan menggunakan atap-atap dak beton. Bentuk-bentuk bangunan yang sangat geometris, dan dipadukan dengan bentuk streamline, merupakan ciri khas dari bangunanbangunan yang dibangun pada tahun 1930-an.
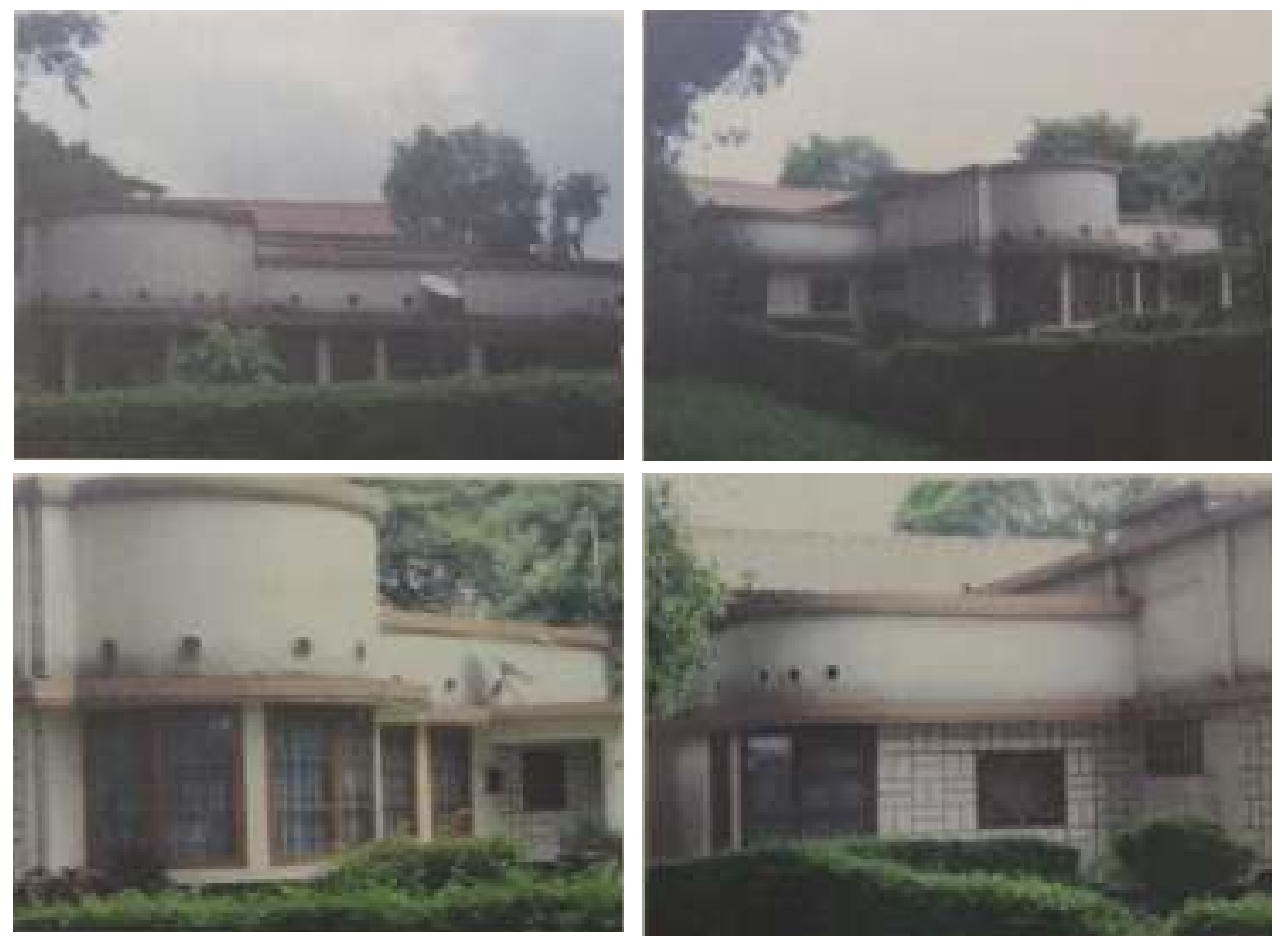

Gambar 3. Bentuk Streamline pada Bangunan 


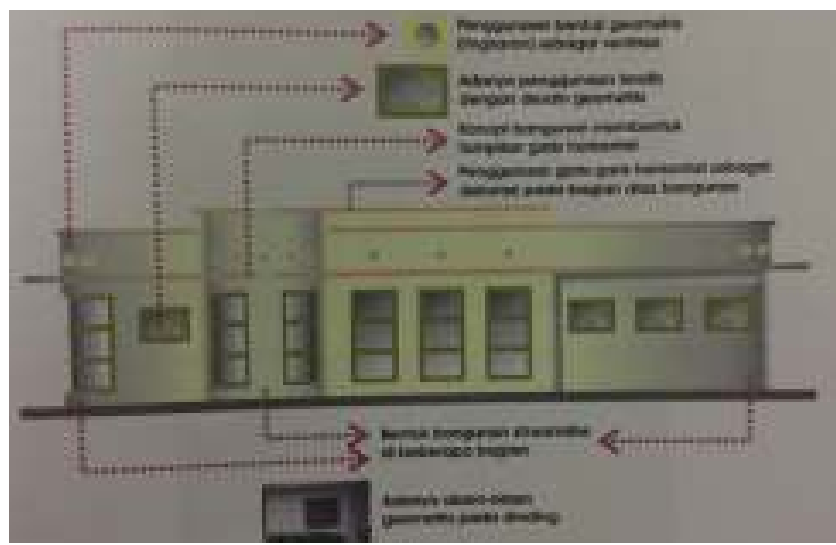

Gambar 4. Analisis pada Bangunan dengan Bentuk Streamline Masif

Pada bangunan di atas banyak menggunakan bentuk-bentuk streamline. Keberadaan kanopi "eyebrow" menciptakan efek garis-garis horizontal. Bentuk kanopi "eyebrow" ini merupakan bentuk kanopi yang berada tepat di atas jendela. Jaraknya yang tidak begitu jauh dari jendela itu menyerupai bentuk alis (eyebrow). Sementara itu, keberadaan dekorasi garis horizontal pada bagian atas bangunan juga semakin mempertegas bentuk bangunan. Pada masa itu, bangunan-bangunan beratap datar selalu memberikan dekorasi berupa garis horizontal pada bagian paling atas bangunan, untuk mempertegas bentuknya. Penggunaan bentukan-bentukan geometris terlihat pada lubang-lubang ventilasi berbentuk bulat, pada teralis dan dekorasi pada dinding.
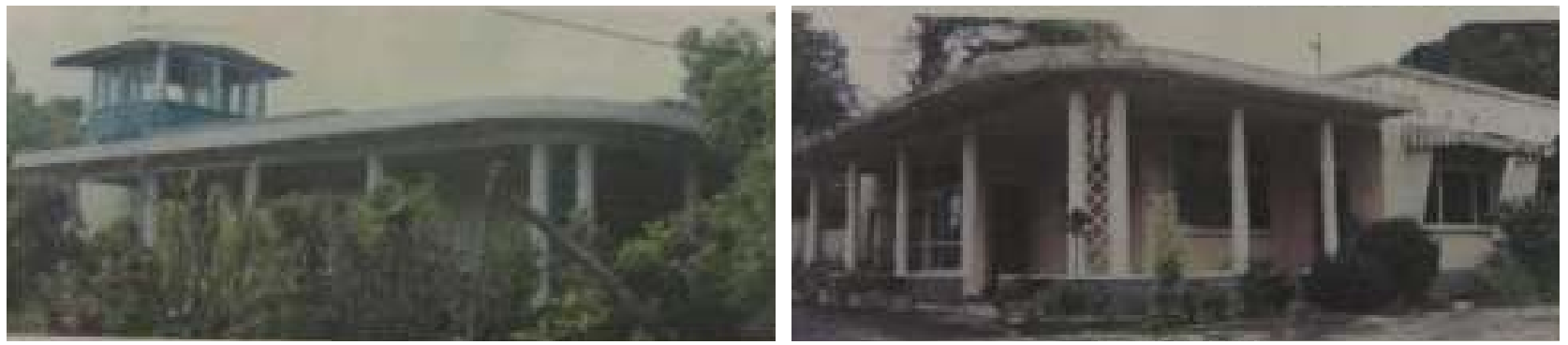

Gambar 5. Bentuk Streamline pada Kanopi Bangunan
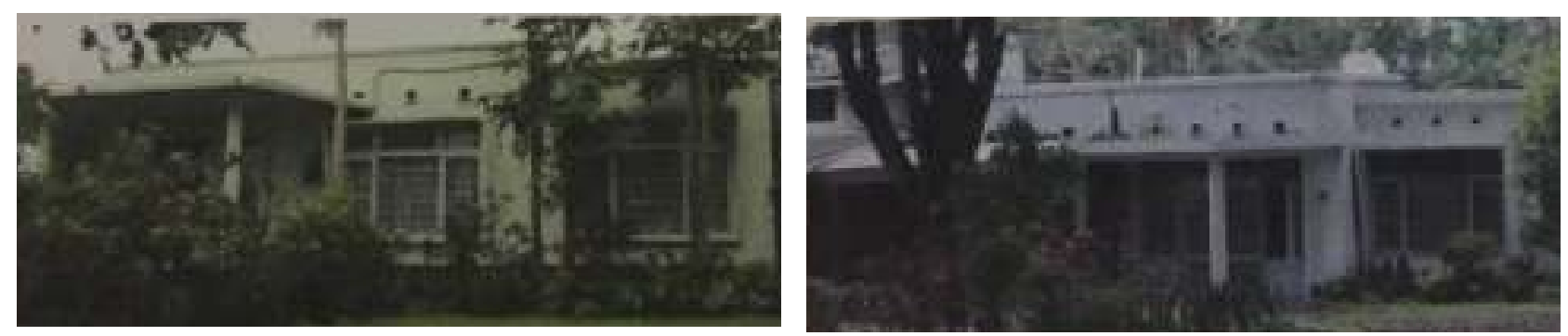

Gambar 6. Bentuk Linear

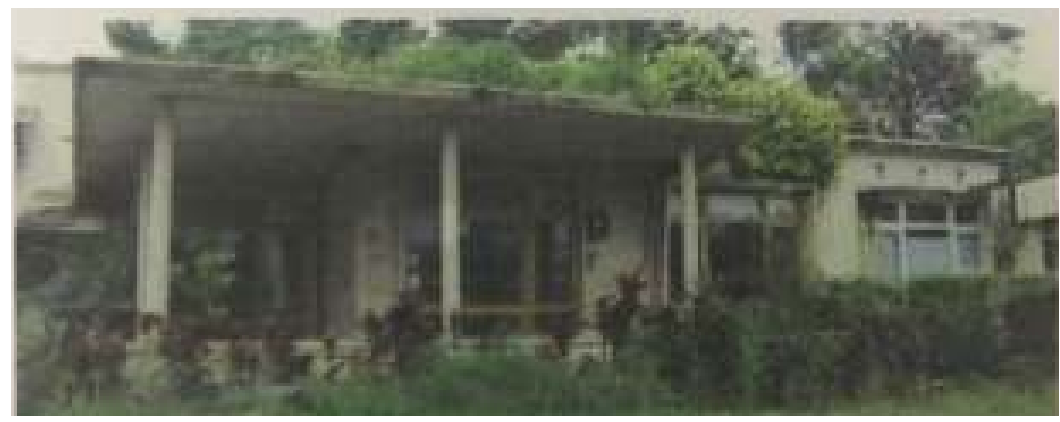

Gambar 7. Bentuk Geometris 


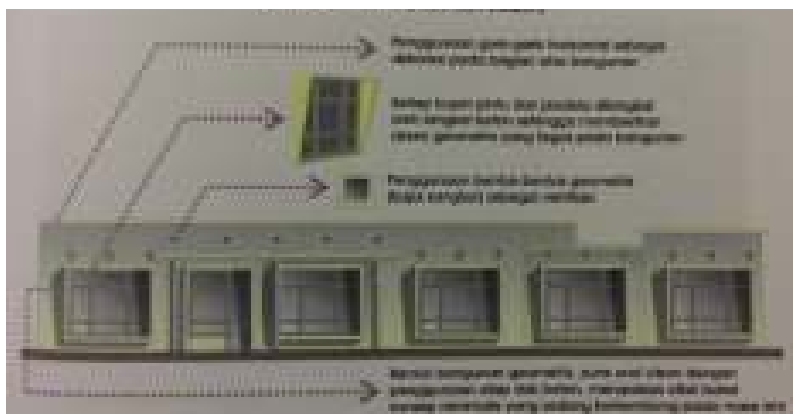

Gambar 8. Analisis pada Bangunan dengan Bentuk Geometris

Gambar di atas merupakan bentuk lain dari bentuk rumah yang ada di komplek Perumahan Dosen UPI ini. Dimana bangunan di atas berbentuk linear masif. Pada bangunan di atas juga terdapat kanopi "eyebrow" yang menciptakan efek garis-garis horizontal. Begitu pula pada garis-garis horizontal yang terletak pada bagian bangunan paling atas. Bentuk geometris atau bujur sangkar diterapkan pada bentuk ventilasi adanya penggunaan bentuk lubang porthole yang membingkai jendela. Porthole merupakan lubang-lubang yang digunakan untuk mengeluarkan mulut meriam pada kapal laut, selain itu juga merupakan jendela pada kapal, bentuknya menjorok ke dalam maupun keluar.

\section{Kesimpulan}

Di Bandung gaya Art Deco banyak diterapkan pada bangunan villa dan rumah tinggal. Kenyataan ini sedikit berbeda dengan yang ada di Eropa dan Amerika, dimana gaya Art Deco banyak diterapkan pada bangunanbangunan publik. Secara garis besar, penerapan gaya Art Deco pada bangunan-bangunan rumah tinggal di Bandung periode Perang Dunia I hingga Perang Dunia II yang berlangsung antara tahun 1914 - 1943, berupa penggunaan bentuk-bentuk streamline plastis maupun masif, atau geometris dan linear, ataupun penggabungan kedua bentuk tersebut pada bentuk badan bangunan. Selain itu, beberapa bangunan juga memadukan bentuk bangunan tropis. Sementara itu, dekorasi yang banyak dipakai adalah berupa garis-garis lurus vertikal dan horizontal, kurva melengkung, bentuk geometris. Penerapan gaya Art Deco nampak terlihat jelas pada bentuk bangunan yang streamline masif khas utilitarian house seperti pada bangunan Tiga Villa. Sementara penerapan gaya Art Deco berupa perpaduan antara bentuk linear dengan bentuk streamline terdapat pada beberapa perumahan dosen UPI. Adapula bangunan yang berbentuk linear masif juga diterapkan pada beberapa bangunan perumahan dosen UPI lengkap dengan lubang- lubang porthole-nya.

Bandung sebagai salah satu kota yang memiliki banyak sekali bangunan dengan gaya Art Deco dengan beragam fungsi bangunan. Diharapkan hasil penelitian ini mampu memperkaya wawasan baik bagi mahasiswa, dosen dan masyarakat luas pada umumnya. Selain itu dengan adanya penelitian ini diharapkan dapat memicu untuk dilakukannya penelitian-penelitian lanjutan secara mendetail terhadap bangunan-bangunan konservasi di Bandung, khususnya bangunan dengan arsitektur Art Deco.

\section{Ucapan Terima Kasih}

Pada kesempatan ini penulis hendak menyampaikan ucapan terimakasih yang mendalam kepada Ibu Dr. Harastoety D. H. yang banyak memberikan masukan mengenai penelitian ini. Penulis juga berterimakasih kepada Bandung Heritage atas data-data mengenai bangunan-bangunan heritage di kota Bandung.

\section{Daftar Pustaka}

Kunto, Haryoto (1984). Wajah Bandoeng Tempo Doeloe. Bandung. PT. Granesia

Dane, Francis C. (1990). Research Methods. California. Thomson Information Publishing Group, Wadsworth Inc.

Duncan, Alastair (__ $)$. American Art Deco. London. Thames \& Hudson Ltd.

Hartono, Dibyo, DR. (2006). Artikel : Arsitektur Art Deco di Indonesia

Hartono, Dibyo, DR. (1997). Artikel : Data Bangunan Bersejarah Kota Bandung. Bandung. Paguyuban Pelestarian Budaya Bandung.

Hartono, Dibyo, DR. (2004). Decorative Art in Architecture As A Part of Bandung History. Bandung. www.arsitekturindis.com

Santoso, Imam. (2017). Penelusuran Historis Melalui Visual Bangunan Art Deco Sebuah Upaya Buffer Kualitas Wajah Kota Ke Era Komersialisasi Di Malang. MINTAKAT Jurnal Arsitektur No. 1 Vol. 1.

Rachmayanti, Sri (2017). Konservasi Bangunan Bergaya Art Deco Di Kota Bandung (Studi Kasus: Hotel Preanger dan Hotel Savoy Homann). Dimensi Vol. 14 No.1 


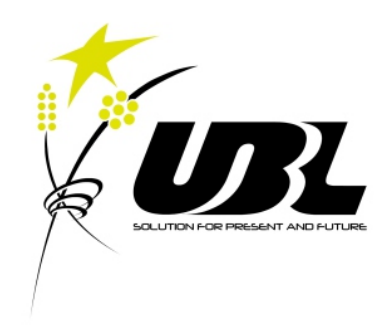

Published:

Program Studi Arsitektur Fakultas Teknik Universitas Bandar Lampung 